\title{
Responses of phytoplankton benthic propagules to macronutrient enrichment and varying light intensities: elucidation from monsoonal estuaries
}

Jagadish S Patil ( $\sim$ patilj@nio.org )

National Institute of Oceanography CSIR

K Sathish

National Institute of Oceanography CSIR

\section{Research Article}

Keywords: Diatoms, Germination, Light intensity, Monsoonal estuaries, Nutrient sources, Phytoplankton benthic propagules, Variable fluorescence

Posted Date: July 21st, 2021

DOI: https://doi.org/10.21203/rs.3.rs-721967/v1

License: (c) (i) This work is licensed under a Creative Commons Attribution 4.0 International License.

Read Full License 


\section{Abstract}

The ecological importance of phytoplankton-benthic-propagules (PBP) from coastal sediments, except tropical-monsoonal-estuaries/coast, is well documented. Monsoonal estuaries recieves a high amount of benthic suspension (sediments, other detritus, PBP, and nutrients) due to high river-discharge during monsoon, bringing drastic changes in the environment (affecting water transparency, macronutrients concentration, and salinity), which in turn influence the plankton and phytoplankton per se. This study elucidates PBP germination and subsequent growth representing downstream, midstream, and upstream locations of monsoon-influenced Mandovi-Zuari riverine systems (Goa, India), to macronutrients (nitrate, phosphate, silicate, and in-combination) and light-intensities at higher salinity. Since, PBP, after introduction to estuary, experience higher salinity conditions with reduced river-discharge salinity of $\sim 35$ PSU was selected. Diatoms dominated the viable PBP community, but the maximum growth and sustained photosynthetic activity were observed when macronutrients were supplied in combination then individual supply. Here, the utility of the variable fluorescence technique in PBP resurrection (detection of viability and responses) was also explored. The PBP lag-period was similar for macronutrients but decreased with an increase in light-intensity. For PBP (germination and photosynthetic activity), lightintensities drive the rate of improvement/development, whereas the nutrients are essential for maintaining vegetative population upon germination. The PBP dominance of common planktonic species (Skeletonema and Thalassiosira) along the river also signifies the role of seawater intrusion in distribution. Both species are light-sensitive, responded similarly, and known to cause single species blooms and contributed significantly to the total community in the region, but on different occasions depending on the species tolerance to salinity.

\section{Introduction}

Phytoplankton, represented by considerable diversity of algal groups (diatoms, dinoflagellates, coccolithophorids, green algae, and blue-green algae), forms an essential component in the functioning of aquatic ecosystems and biogeochemical cycles. Most phytoplankton groups have some known resting stages (e.g., specialized resting spores or resting cells or cysts), formed asexually or sexually, as survival alternatives in an adverse environment to maintain their population. These stages are commonly known to provide short- or long-term survival and may also contribute to natural dispersal by currents or when transported in ballast water tanks [1]. There is also a hypothesis that (i) resting stages anchor a population at a particular site [2-3], and (ii) also have the potential to provide an inoculum that influences present populations through "dispersal from the past" (the storage effect; 4]. These resting stages are dormant and serve as a refuge during adverse conditions, such as a change in temperature, salinity, $\mathrm{pH}$, and especially nutrient depletion [5; 6]. Once resting stages are formed, they sink to the bottom and become a part of the benthos as benthic propagules. Resting stages are reported to play central roles in evolutionary resilience and survival of catastrophic events [7]. Though phytoplankton resting strategies are ecologically important, understanding their impacts will also aid in managing water bodies used by multiple industries [8]. The rich abundance of benthic propagules protects themselves in coastal 
sediments during periods not suitable for vegetative growth. In most cases, resting stages are a survival mechanism for disturbances occurring on various timescales and can remain viable for up to about a century in sediments [eg. 7, 9-11].

Viable 'banks' of phytoplankton resting stages have been reported from marine sediments all over the world, encompassing different ecosystems such as bays, coastal waters, estuaries, fjords, and polar regions, including examples from the bays/fjords of Scandinavia [12-14], United Kingdom [15], continental Europe [16), bays and coastal waters of Asia '[9, 17-18], Mediteranean sea [19], Bering Sea [20], Arctic sea [21] and even after a century of dormancy from Koljo Fjord [12]. Freshwater studies have also recorded viability in resting stages '[22] after decades in the sediments. Viable phytoplankton benthic resting stages or benthic propagules (PBP) repopulated waters if resuspended and switch to active growth following germination. Several environmental factors such as light, temperature, salinity, and nutrients are known to trigger the germination of PBP [23-25]. After the germination, cells growth is further controlled by several factors, such as temperature, light intensity, nutrient concentration, inter-and intraspecific competition, and grazing [26]. Germination of resting stages and successful growth of newly germinated vegetative cells can play a significant role in coastal micro-plankton dynamics and bloom formation [27-28]. For micro-phytoplankton in coastal areas, vegetative division alone cannot explain the increases in the population. Environmental cues that control resting stage germination and growth may determine the seasonal patterns of a species (e.g., when a species appears in the plankton) and the population's overall success. Therefore, it is essential to understand how environmental factors regulate germination and growth on a species-by-species basis.

In India, even though a considerable amount of information on the role of environmental drivers on the variations in phytoplankton are available, the information on viable PBP is limited [18, 29]. Field-based findings suggested that in shallow tropical regions, physical processes during monsoon (freshwater discharge) and non-monsoon seasons (currents, waves, and tides) cause resuspension followed by transportation (e.g., from upstream to downstream and vice versa due to river discharge and tides, respectively) of benthic propagules along with sediment and other detritus, which in turn influences water transparency and nutrient concentrations [18]. Although the benthic propagule community is dominated by planktonic species known to form seasonal blooms in the region, no direct attempts have been made to identify the environmental cues responsible for triggering germination and its subsequent vegetative growth. Therefore light (water transparency) and macronutrient availability are considered environmental cues because they are the major growth controlling factors for phytoplankton in the region [18, 30-31]. Given this, the present study investigates PBP responses (germination and its subsequent growth) to different macronutrients and light intensities at higher salinity from a monsoon-influenced tropical estuarine system. Generally, the dominance of freshwater and marine conditions is more during monsoon (June to September) and non-monsoon months (October to May), respectively. Therefore, the higher salinity was selected because the introduced PBP will experience higher salinity conditions until the return of the next monsoon i.e., after approximately eight months. Since the study was conducted before the onset of the monsoon, the findings will unravel the distribution and fate of PBP introduced by river discharge in the estuary where salinity is higher.

Page $3 / 23$ 


\section{Materials And Methods}

\section{Sampling locations}

Mandovi and Zuari estuaries located along the central west coast (Goa coast) of India are the dynamic aquatic ecosystems exhibiting a strong seasonal gradient, both in environmental variables and plankton assemblages, because of the tight physicochemical and biological coupling. The rivers Mandovi and Zuari, together with the Cumbarjua canal, form a major estuarine system in the region (Fig. 1a). Both rivers originate in Sahyadri hills in the Western Ghats. The Mandovi River traverses $\sim 75 \mathrm{Km}$, while the Zuari River $\sim 70 \mathrm{Km}$, from their respective places of origin before entering the Arabian Sea along the west coast of India. The narrow Cumbarjua canal about $11 \mathrm{Km}$ and $14 \mathrm{Km}$ away from Mandovi and Zuari estuaries' mouth interconnects the estuaries, respectively. This area is strongly influenced by the southwest monsoon (June to September). The changes associated with its onset have marked effects on the phytoplankton community, food-web, and production [18,30]. During monsoon, surplus influx from river, and precipitation ( $275 \mathrm{~cm}$, i.e., $80 \%$ of annual rainfall), is added to the estuary resulting freshwater dominance. In the Zuari estuary, almost marine conditions prevail with a bit of freshwater drainage from the river during post-monsoon months. In contrast, in the Mandovi estuary, the freshwater discharge continues throughout the year.

\section{Collection of sediment samples}

The sediment samples were collected from three stations, each along the Zuari (Z1 - Mormugao; Z2 Cortalim, and Z3 - Sanvorderm) and Mandovi (M1 - Campal; M2 - Amona, and M3- Usgoa) rivers during January 2011 (Fig. 1a; Suppl Table 1). The stations selected represented upper, middle, and lower regions, covering a wide range of salinities from freshwater in the upstream area to seawater at the mouth.

Samples from Zuari and Mandovi were collected on $10^{\text {th }}$ and $12^{\text {th }}$ January 2011 , respectively. Sediment samples from each station were collected using a modified van Veen grab (grabbing area of $\left.0.04 \mathrm{~m}^{2}\right)$, which is equipped with flaps on the top side, enabling the collection of surface sediments using cores. The uppermost sediments $(0-2 \mathrm{~cm})$ using 2-3 cores (PVC cores, $25 \mathrm{~cm}$ long, the inner diameter of $2.5 \mathrm{~cm}$ ) were obtained from the grab. The collected sediment samples were then sealed in airtight bags and then kept cool $\left(4^{\circ} \mathrm{C}\right)$ in the dark for more than three weeks to reduce viable vegetative cells. Few studies indicated the dark storage at relatively low temperatures was influential in selecting resting stages while eliminating recently settled vegetative cells [32].

\section{Inocula preparation for the experiment}

A stock solution was prepared for the inocula preparation by mixing an aliquot of known weight $(3.5 \mathrm{~g}$ wet wt) of sediment with $35 \mathrm{ml}$ sterile filtered seawater (SFSW) to achieve a $0.1 \mathrm{~g} \mathrm{ml}^{-1}$ concentration. For the $250 \mathrm{ml}$ and $125 \mathrm{ml}$, experimental bottles $1 \mathrm{ml}$ and $0.5 \mathrm{ml}$ of the stock solution were added as inocula.

\section{Experimental setup}


All the experiments were conducted in the laboratory. The experiments to evaluate the responses of estuarine phytoplankton benthic propagules (PBP) to different nutrient sources and light intensities were conducted parallel (Fig. 1b). However, these experiments were performed separately for sediments collected from the Zuari and Mandovi rivers. For the experiments, $20 \mathrm{~L}$ of seawater ( 34.74 PSU) collected from Dona Paula Bay of Zuari estuary was used. Before use, the collected water was filtered through $0.22 \mu \mathrm{m}$ millipore filter paper followed by steam sterilization at $120^{\circ} \mathrm{C}$ and cooling at room temperature. This water was used for conducting two experiments. The first and second experiments correspond to the sediments collected from Zuari and Mandovi estuaries. In each experiment, the sediment collected from three stations was used in parallel. Fourteen Nalgene polycarbonate bottles with capacities $(250 \mathrm{ml}$ and $125 \mathrm{ml}$ ) were used for one station. In each of these bottles, SFSW was poured aseptically, i.e., $250 \mathrm{ml} \mathrm{SFSW}$ water in $250 \mathrm{ml}$ bottles and $125 \mathrm{ml} \mathrm{SFSW}$ in $125 \mathrm{ml}$ bottles. All these bottles were then enriched with $f / 2$ trace metals and vitamins. These bottles were then incubated as detailed below to elucidate the different macronutrient and light intensity effects on PBB.

\section{Effect of nutrients on phytoplankton benthic propagules}

In this experiment effect of types of macronutrients such as nitrate- $\mathrm{N}$, phosphate- $\mathrm{P}$, silicate- $\mathrm{Si}$, and in combination (NPSi) on PBP responses was evaluated. For the experiment, ten $250 \mathrm{ml}$ Nalgene bottles containing trace metal-enriched SFSW were used. Of these, two bottles each were enriched with phosphate $\left(\mathrm{Na}_{2} \mathrm{H}_{2} \mathrm{PO}_{4} \cdot \mathrm{H}_{2} \mathrm{O}-250 \mu \mathrm{l}\right.$ from $3.62 \times 10^{-5} \mathrm{M}$ stock solution), nitrate $\left(\mathrm{NaNO}_{3}-250 \mu \mathrm{l}\right.$ from $8.82 \times 10^{-4} \mathrm{M}$ stock solution), silicate $\left(\mathrm{Na}_{2} \mathrm{SiO}_{3} \cdot \mathrm{H}_{2} \mathrm{O}-250 \mu \mathrm{l}\right.$ from $1.06 \times 10^{-4} \mathrm{M}$ stock solution) and in a combination NPSi. The preparation of the above nutrients' stock solution is the same as that for the preparation of $f / 2$ stock solutions [33]. The remaining two bottles without nutrient addition were treated as the experimental control. In all these bottles, $1 \mathrm{ml}$ of inocula prepared from the collected sediment was added. After addition, the bottles were gently swirled and incubated for 13 days in the temperaturecontrolled room $\left(25 \pm 1^{\circ} \mathrm{C}\right)$ with a $12: 12 \mathrm{~h}$ light: dark cycle at a light intensity of $70 \mu \mathrm{mol}$ photons $\mathrm{m}^{-2} \mathrm{~s}^{-1}$. Hereafter, the light intensity selected here is regarded as medium light $(\mathrm{ML})$. During the incubation period, phytoplankton's progression in each treatment was monitored through fluorescence measurements $(0,2,4,7,9$, and 13 days) and cell counts $(0,2,7$, and 13 days). Similarly, the above procedure was repeated for the sediments collected from Zuari and Mandovi. The experiments with Zuari ( $7^{\text {th }}$ to $20^{\text {th }}$ February 2011) and Mandovi (25 ${ }^{\text {th }}$ February to $11^{\text {th }}$ March 2011) were conducted separately.

\section{Effect of light intensities on phytoplankton benthic propagules}

In this experiment, PBP responses to varying different light intensities on PBP was elucidated. These experiments were performed simultaneously, using four $125 \mathrm{ml}$ bottles containing SFSW enriched with full strength nutrient concentrations (NPSi), with the above experiment. In all these bottles, $0.5 \mathrm{ml}$ of prepared sediment inocula were added. After addition, the bottles were gently swirled and incubated similarly, as mentioned in the above section, at two different light intensities, $25 \mu \mathrm{mol}$ photons $\mathrm{m}^{-2} \mathrm{~s}^{-1}$ 
(low light $-\mathrm{LL}$ ) and $300 \mu \mathrm{mol}$ photons $\mathrm{m}^{-2} \mathrm{~s}^{-1}$ (high light $-\mathrm{HL}$ ). The Secchi disc depth (indicative of water transparency) in the monsoon estuary varies between $<0.5 \mathrm{~m}$ to $3.5 \mathrm{~m}$, and the lowest is observed during peak discharges during monsoon and the maximum during monsoon breaks and non-monsoon months [34]. Therefore, the light intensity selected is an indicator to confirm the role of light intensity on the PBP germination and subsequent growth. For LL, two bottles were wrapped with neutral density screens and incubated in the same temperature-controlled room as above. In contrast, $\mathrm{HL}$ bottles were set in a versatile environment test chamber at $25 \pm 1^{\circ} \mathrm{C}$ (model: SANYO). Since all the nutrient experiments were conducted under $\mathrm{ML}$, the observations carried out from bottles with full strength nutrients (NPSi) were used to compare with the observations done for $L L$ and $\mathrm{HL}$ bottles. The photocycle and the interval for monitoring the progression of growth are the same as detailed above. The procedure was repeated with sediment samples collected from Zuari and Mandovi rivers.

\section{Parameter analyzed in the experiments}

Samples for the analysis of chlorophyll fluorescence, photosynthetic parameters, phytoplankton counts, and taxonomic composition were collected on each sampling occasion during all the experiments. Inorganic nutrients (nitrate, phosphate, and silicate) were analyzed by following standard procedures using a spectrophotometer (Shimadzu Model-2450) during the start (day 0 ) and end of the experiments, i.e., day 13 [35].

Chlorophyll (chl) fluorescence was measured on each sampling occasion through in vivo chlorophyll fluorescence measurements of the samples using Trilogy (Turner designs), equipped with a chlorophyll module. Further, the fluorescence induction and relaxation (FIRe) technique, using FIRe fluorometer (Satlantic Inc.), was used to monitor cells' viability and photosynthetic performance. The FIRe measurements details for sediment samples (including sample preparation) are published elsewhere [36]. Unlike water samples, the background corrections for sediment samples are not straightforward. The only possible way for assessment is first to prepare the inocula of the sediment samples followed by suspension in a known volume of sterilized growth media followed by incubation in proper growth condition for several days till the signal of the growth is observed. FIRe measurement of the inocula/resuspended sample (day 0 ) will indicate viable cells presence. The measurements done during incubation will determine the time taken for growth. The method is rapid and non-destructive. The FIRe fluorometer measures a suite of photosynthetic parameters such as the initial $\left(F_{0}\right)$, maximum $\left(F_{\mathrm{m}}\right)$, and variable $\left(F_{\mathrm{v}}=F_{\mathrm{m}}-F_{0}\right)$ components of photosystem II (PSII) fluorescence, quantum yield $\left(F_{\mathrm{v}} / F_{\mathrm{m}}\right)$, and functional absorption cross-section $\left(\mathrm{s}_{\mathrm{SII}}\right)$, which can be used to assess the physiological status of the phytoplankton. The fluorescence transients were measured using a FIRe fluorometer. Before measurements, the samples were dark-adapted for $30 \mathrm{~min}$. The gain was adjusted depending upon the chl concentration of the sample taken for analysis. The curve-fitting procedure was performed by using the FIRePro software.

For phytoplankton analysis, $5 \mathrm{ml}$ of the samples were preserved with Lugol's solution in duplicates. The analysis was carried out using a counting chamber having a grid of 20X20 under an inverted microscope 
(Olympus IX71) equipped with a camera at a magnification of 20x. Phytoplankton was identified based on the standard identification keys [http://www.algaebase.org/, 37]. Univariate measures (species count, Shannon-Wiener diversity, and evenness) were calculated using PRIMER ver.5.

\section{Results}

\section{Inocula description}

Microscopic observations that diatoms dominated the sediment inoculum prepared from the sediment sample collected from the Zuari and Mandovi rivers. The major taxa in the sediment inoculum of Zuari were Navicula, Skeletonema, Coscinodicsus, Gyrosigma, Ditylum, Trigonum, Cymbella, Grammatophora, Pleurosigma, and Thalassiosira. Whereas in the sediment inoculum of the Mandovi river, the major taxa were Chaetoceros, Coscinodiscus, Grammatphora, Navicula, Skeletonema, Thalassionema, and Thalassiosira. The prepared inocula's total cell counts ranged from 70 to 180 cells ml $^{-1}$ in Zuari and 135 to 190 cells $\mathrm{ml}^{-1}$ in Mandovi. The chl fluorescence values ranged from 434 to 523 (au) for the Zuari river, and for the Mandovi river, the values ranged from 82 to 250 (au) (Fig. 2). The FIRe measurements on sediment inocula showed a somewhat flat curve instead of the induction curve typically observed for the live organisms curve. The variable chlorophyll fluorescence ( $F_{v}$; a proxy for viability) of the inocula was almost the same to that of the initial and final fluorescence (Fig. 3; Suppl Fig. 1), whereas the photochemical efficiency was very low $\left(F_{\mathrm{v}} / F_{\mathrm{m}}=<0.2\right)$ and $\mathrm{s}_{\mathrm{PSII}}$ was unrealistic (Fig. 4; Suppl Fig. 2). These initial values for PSII parameters suggested that the sediment sample used for incubation harbored very low viable chlorophyll (in the undetectable range) with reduced quantum efficiency.

\section{Effect of different nutrient sources on PBP}

The nutrient analysis revealed that the macronutrients (nitrate, phosphate, and silicate) were not limited in all the treatments at the beginning of the experiments. However, on day 13 (the last day of the experiment), only the nitrate was limiting in control, phosphate, and silicate supplied bottles (Suppl Table 2). The chl fluorescence values indicated that the increase in fluorescence values was not observed initially for some days in all the treatments (Fig. 2). In the case of Zuari, chl increase was not observed up to seven days, whereas, in the case of Mandovi, chl increase was not observed until day seven (for M1 and M2 stations) and day nine for M3 station. However, significant increases in fluorescence values were observed from day seven onwards, indicating that the phytoplankton growth started after day 4 (Fig. 2; Suppl Fig. 1). Such a long lag phase was due to the presence of dormant benthic propagules or resting stages. Even the variable fluorescence $\left(F_{\mathrm{v}}\right)$ responded similarly (Fig. 3). ANOVA showed significant variations between the macronutrient treatments, i.e., maximum and minimum fluorescence values (raw fluorescence, $F_{0}$, and $F_{\mathrm{v}}$ ) were observed for NPSi and control treatments, respectively as well as days of incubation $(p \leq 0.001)$. However, improvements in photosynthetic efficiency, $F_{v} / F_{m}$ values, in most of the treatments, were observed from day two onwards and reached the maximum on the fourth day and remained the same till the end of the experiment, i.e., Day 13 (Fig. 4). ANOVA showed insignificant variations between the macronutrient treatments and significant variations concerning days of 
incubation $(p \leq 0.001)$. In the case of $s_{P S I I}$, the initial unrealistic values $(>1000$ or $<200)$ were found to fall in the normal range upon incubation (Suppl. Fig. 2). These variations in fluorescence parameters were noticed in all the treatments.

The Zuari and Mandovi's PBP responses also showed a similar trend concerning the nutrient treatment and incubation period (Fig. 5). The species count remained almost constant with nutrient treatment and incubation period, which was observed for Zuari and Mandovi (Fig. 5). Initially, the diversity of the benthic propagules was high and evenly distributed. From day seven onwards, the increase in the population of some diatoms resulted in a decrease in diversity and evenness values. This was observed in all the treatments (Fig. 5). Species composition data revealed that 21 diatom species were recorded, of which 19 and 17 species belonged to Zuari and Mandovi, respectively. The abundance of these diatoms in each treatment with time is presented in Figure 5. In Zuari, Skeletonema was the most dominant species, followed by Thalassionema, Navicula, Grammatophora, and Coscinodiscus (Fig. 6). In Mandovi Thalassiosira, followed by Thalassionema, Skeletonema, Navicula, and Coscinodiscus were dominant species except for M1 station (Fig. 6). In station M1, Thalassionema was more prevalent than Thalassiosira. Irrespective of nutrient sources, the species composition in both Zuari and Mandovi was the same. The maximum abundance was observed when the macronutrients were supplied in combination (nitrate+phosphate+silicate) compared to the individual nutrient source.

\section{Effect of different light intensities on PBP}

The effects of different light intensities on chl fluorescence, abundance, species count, diversity, and evenness are presented in figures 2, 7, and 8 . The chl fluorescence results indicated that light intensities play a significant role in the PBP germination and subsequent growth. This was observed for both the rivers (Zuari and Mandovi), and in both the cases ANOVA showed significant variations between the light intensities ( $p \leq 0.001)$, i.e., maximum and minimum fluorescence values were observed for $\mathrm{HL}$ and $\mathrm{LL}$ treatments, respectively as well as days of incubation $(p \leq 0.001)$. The increase in chlorophyll (as evidenced from raw and variable fluorescence) for $\mathrm{HL}, \mathrm{ML}$, and $\mathrm{LL}$ was observed from four, seven and thirteen days (Fig. 2, 5; Suppl. Fig. 1), respectively. Even $F_{\mathrm{v}} / F_{\mathrm{m}}$ values were found to be increasing from day two onwards in all the light treatments, but the magnitude was more in HL (Fig. 4). ANOVA revealed significant variations between light intensities $(p \leq 0.001)$ and days of incubation $(p \leq 0.001)$. $s_{P S I I}$, unlike that observed in nutrient treatments, the initial unrealistic values $(>1000$ or $<200)$ were found to fall in the normal range upon incubation and remained in the same range till the end of the experiment (Suppl. Fig. 2). The $s_{P S I I}$ were found to be relatively lower and higher under low and high light conditions between the light treatments, respectively (Suppl. Fig. 2). These results indicate that the high light intensities led to the shorter lag period and marked improvements in photosynthetic efficiency compared to ML and LL. It was thereby confirming that the light intensity is one of the critical environmental factors in determining the lag period's duration for the PBP growth and the photosynthetic activity.

PBP's response for Zuari and Mandovi also shows a similar pattern concerning different light intensities and incubation periods (Fig. 7). The increase in abundance was observed with an increase in light 
intensities. However, the species count remained almost constant with the incubation period and light treatment for Zuari and Mandovi (Fig. 7). Initially, irrespective of light intensities, the diversity of the benthic propagules was high and evenly distributed. From day seven, diversity and evenness values decreased with an increase in some diatom populations (Fig. 7). Altogether 17 species belonging to only diatoms each were recorded from Zuari and Mandovi (Fig. 8). The abundance of these diatoms for each light treatment concerning days of incubation is presented in Figure 8. The species composition and the dominance pattern seen in this experiment are the same as above for nutrient experiments. In Zuari, Skeletonema was the most dominant species, followed by Thalassionema, Navicula, Grammatophora, and Coscinodiscus (Fig. 8). In Mandovi, Thalassiosira followed by Thalassionema, Skeletonema, Navicula, and Coscinodiscus were dominant species except for M1 station (Fig. 8). In station M1, Thalassionema was dominant than Thalassiosira. Irrespective of light intensity, the species composition in Zuari and Mandovi was the same, and the maximum abundance was observed under high light compared to the supply of low light levels.

\section{Discussion}

\section{Phytoplankton benthic propagule (PBP) viability and community in the estuaries}

The present study demonstrated that the PBP present in the sediments representing the upper, middle, and lower regions of the Zuari and Mandovi rivers are photosynthetically inactive. The variable fluorescence $\left(F_{\mathrm{v}}\right)$, an indicator for cell viability [36], suggested that the PPB was photosynthetically not viable at the start of the experiment. However, they were capable of reviving viability and photosynthetic activity, i.e., increase in $F_{\mathrm{v}}$ and $F_{\mathrm{v}} / F \mathrm{~m}$ due to vegetative growth after germination under $\mathrm{I} 2 \mathrm{~h}$ light: dark photocycle and macronutrients (Figs. 2 to 5; Suppl Fig. 1). Interestingly, the revival of PBP was also observed from those samples representing the middle and upper regions of both the rivers when incubated in the nutrient-enriched 35 PSU seawater. Further, this study also demonstrates the utility of the variable fluorescence technique in the resurrection studies (detection of photosynthetic viability and responses to environmental cues). Resurrection ecologists have long recognized sediments as sources of viable propagules ("seed or egg banks"), including diatoms, with which to explore questions of community ecology, ecological response, and evolutionary ecology [38]. Generally, diatom benthic stages and dinoflagellate cysts represent PBP. Still, in this study, only the response of diatoms was observed, indicating their dominance to the viable PBP pool present in the stations representing upper, middle, and lower regions of the Zuari and Mandovi rivers. The available information from the area suggests dinoflagellate cyst abundance is very low (a few hundred per gram of dry sediment), which could be one reason for their no response in the incubation. Nevertheless, the focus is on the PBP, which responded to the treatments and contributed significantly to the region's phytoplankton dynamics.

Altogether, 21 diatom species were recorded after incubation (Figs. 6 and 8), and the following species Skeletonema, Thalassionema, Thalassiosira, Navicula, Grammatophora, and Coscinodiscus dominated the BP community. The occurrence pattern of these forms in the estuarine system is as follows: 1 . the propagules of Skeletonema, a bloom-causing species along the west coast of India, including the present 
estuarine system, are present from downstream to upstream up to several kilometers in Zuari and Mandovi rivers respectively. In Zuari, the cell abundance of Skeletonema after incubation is higher compared to Mandovi; 2. The presence of Thalassionema propagules is restricted from downstream to midstream in both Zuari (Z1 and Z2) and Mandovi (M1 and M2) rivers; 3 . The propagules of Thalassiora are present only in the stations along Mandovi, and it's high cell abundance after incubation was observed in midstream and upstream sediments (M2 and M3) compared to downstream (M1); 4. Navicula, Grammatophora, and Coscinodiscus are present in the upper, middle, and lower Zuari and Mandovi rivers regions. The cell abundance of these species after incubation is low compared to the three dominant species. Nevertheless, the dominant species' presence from the down to upstream stations can be attributed to tides. During non-monsoon, tidal advection from the sea to the upstream is dominant than river discharge. It has been observed that during the spring tide of the season, the salinity of $\sim 1.5$ is observed at the upstream location i.e., $\sim 40 \mathrm{Km}$ from the mouth [39], corroborating the role of tides in the widespread distribution of the PBP in the region. However, this aspect needs to detailed investigation.

The resting stages are formed to overcome unfavorable environmental conditions such as nutrient limitation, light, low temperature, salinity fluctuation, and internal regulation [25, 40,41]. Recent findings also indicated a link between cell density and spore formation in the diatom Chaetoceros socialis [41]. Several studies demonstrated that nitrogen depletion is the most important environmental variable for forming resting stages in several microalgae including diatoms [25,]. A field-based study in Zuari estuary also revealed that the bloom's termination coincided with nitrate depletion and a corresponding increase in benthic propagules $[18,31]$. However, the onset of favorable conditions such as non-limiting nutrient concentration, appropriate combinations of temperature and light conditions (duration, quality, and quantity) seem to favor resting stages to germinate [23, 25, 42-44]. In tropical regions, water temperature variations are minimum compared to temperate areas, and therefore temperature may not be a significant factor. Previous field studies indicated that the peaks in chlorophyll coincided with improved underwater light conditions (except during peak monsoon discharges and periods of the high suspended load during non-monsoon), nutrients influx, and relatively high salinity (except during peak discharges) $[18,30,31]$. Given these specific experiments were performed and are discussed subsequently.

\section{Phytoplankton benthic propagule (PBP) responses to macro-nutrients}

The availability of nutrients (such as nitrate, phosphate, silicate) in addition to carbon dioxide, sunlight, and micronutrient is a known fact affecting the phytoplankton life cycle (including resting stage formation and germination). Nutrient enrichment experiment indicated that the maximum growth was observed when the macronutrients were supplied in conjunction (NPSi) compared to the availability of individual nutrient sources. This was supported by the fluorescence (both raw and variable fluorescence) as well as abundance data. The species composition in each treatment was the same, and this was observed in both Zuari and Mandovi sediments. For Zuari samples, significant PBP growth was observed from day seven onwards. In Mandovi, significant PBP growth was observed from day seven (for downstream and midstream stations) and day thirteen for the upstream station. Previous studies also 
reported a 1 to 8 days lag period compared to vegetative cells, which can grow almost immediately [27, 29,42 ]. Even the photosynthetic efficiency remained low during the lag period but showed a drastic improvement upon the commencement of the growth after the end of the respective lag period (Fig. 3 and 4). Such a delayed lag period is because the benthic propagules first need to germinate, followed by asexual growth, whereas the vegetative cells just need to grow asexually. Another reason for prolonging the lag period could be fewer resting stages in the inoculum [29]. However, this was not the case in this study as the sediment samples harbored sufficient propagules, but there could be other limiting factors (e.g., light) for the long lag period. Further, the prolonged lag period for the PBP growth was almost the same irrespective of nutrient sources, indicating that the nutrients might be playing a minor role in the germination of diatoms. However, upon germination, subsequent growth success depends on nutrients availability, which was evident irrespective of the sample's origin. The experimental data further indicated that enhanced growth was observed even when supplied with any macronutrients compared to control. Still, the highest increase will be observed when all macronutrients (NPSi) are available.

\section{Phytoplankton benthic propagule (PBP) responses to light intensities}

Germination of individual cells appears to occur whenever sediments are exposed to a well-lit zone. Several studies have indicated that the photoperiod i.e. day length [23], intensity/irradiance [45-47], and quality such as spectral wavelength, e.g., blue, light [44] are known to influence the germination. The day length does not vary significantly in the tropical region, unlike the high latitude and temperate areas. Montresor et al. [47] indicated the day length theory holds the key for the germination of high latitude species but does not seems to be affected by changes in the day length for temperate species. Therefore it is presumed that the day length, which varies between 12 to $14 \mathrm{~h}$ depending upon the season, should not be a limiting factor in the Indian subcontinent and most probably for tropical species.

Laboratory experiments showed that a threshold irradiance is required to induce germination and subsequent growth $[45,46]$ but not mandatory as the resting stages of a diatom Aulacosira can germinate in dark conditions [65]. Earlier works have indicated that diatom resting stages can germinate within few days when exposed to light conditions $[25,40,45,49]$ and can have fully developed plastids after four days [50]. Research indicated an increase in the germination rate concerning increasing light intensity from 300 to 4000 lux, which was also evident in the present study [47]. Fluorescence (both raw and variable fluorescence) and abundance data indicated that the maximum growth of PBP was observed under $\mathrm{HL}\left(300 \mu \mathrm{mol}\right.$ photons $\left.\mathrm{m}^{-2} \mathrm{~s}^{-1}\right)$ followed by $\mathrm{ML}\left(70 \mu \mathrm{mol}\right.$ photons $\left.\mathrm{m}^{-2} \mathrm{~s}^{-1}\right)$ and $\mathrm{LL}(25 \mu \mathrm{mol}$ photons $\mathrm{m}^{-2} \mathrm{~s}^{-1}$ ). Even the photosynthetic efficiency also followed a similar trend initially but remained maximum until the end of the experiment. However, the species composition remained the same under all light intensities for the respective samples. The experimental results also indicated that the light intensities play a major role in deciding the lag periods duration required for the germination and subsequent growth of PBP, i.e., higher light intensities affect a shorter lag period compared with lower light intensities. The lag period for Zuari and Mandovi sediments was same; the lag period in $\mathrm{HL}, \mathrm{ML}$, and LL was four, seven, and thirteen. It should also be noted that germination rates showed speciesspecific responses to light intensity and could affect species succession patterns when species were 
exposed to light. In this study, the germination rates of the dominant diatom species were more under $\mathrm{HL}$ conditions. Skeletonema and Thalassiosira, common planktonic species, were more sensitive to light, and both responded similarly to the light levels.

Previous studies revealed that both Skeletonema and Thalassiosira are dominant in the sediments during all the seasons and were reported to form blooms in the region but on different occasions [18].

Skeletonema blooms were observed under lower (during monsoon as single species) and higher (during monsoon break or non-monsoon mixed species) salinities. In contrast, Thalassiosira blooms were observed mainly during the non-monsoon season at higher salinity [18, 31]. However, the Skeletonema population outbreak's magnitude was more significant than Thalassiosira [18]. Although blooms of these species occurred on different occasions, the bloom-forming mechanism for both is the same. For instance, the physical disturbances inducing benthic resuspension causing lower water transparency, nutrients influx, propagule transfer to the surface (photic zone) followed by germination when exposed to light, and the vegetative cells that arise from the sediment inoculum proliferate under nutrient-replete conditions. However, the nature of physical forcings inducing benthic resuspension is different during monsoon and non-monsoon seasons. The physical forcings associated before Skeletonema and Thalassiosira blooms are the freshwater discharge (during monsoon) and the local processes (during non-monsoon), respectively. Although the species' benthic propagules get resuspended, the species' tolerance capabilities to salinity could be the dominant factor that led to causing the population increase not to co-occur in the region. Further, both the species lag period depends on the magnitude and duration of the factors such as benthic resuspension and cloud cover affecting the light availability but not to the extent of growth-limiting levels. During the initiation of Skeletonema bloom, light availability is governed by both benthic resuspension and cloud cover (only during monsoon). In contrast, for Thalassiosira blooms, only benthic resuspension will influence light availability.

\section{Conclusion}

We investigated the role of different nutrient sources and light intensities on the germination and subsequent growth of PBP representing downstream, midstream, and upstream locations of the monsoon-influenced riverine systems. At the same time, it is clear that the distribution of viable diatom benthic propagules, having negligible variable fluorescence signals or efficiency, is spread along with the monsoonal riverine systems. It is evident from the dominance of most common planktonic forms in the sediments. Specific experiments suggested that light intensities play a major role in germination and the nutrients on the germinated cells' growth. Though maximum photosynthetic efficiency was observed in light (intensity) and nutrient treatments, the rate of improvement was driven by light intensity.

Skeletonema and Thalassiosira (common planktonic species and most dominant PBP) responded similarly to the light levels and are known to form blooms in the region but on different occasions. However, the mechanism of bloom formation for both is the same, the species tolerance capabilities to salinity a possible explanation for species seasonality in the monsoonal estuaries' plankton. However, further research considering salinity and the associated parameter is essential for better understanding the bloom-forming species benthic-pelagic coupling. 


\section{Declarations}

\section{Acknowledgments}

The authors are grateful to the Director, CSIR-National Institute of Oceanography (Goa, India), and Dr. AC Anil for their support and encouragement. J.S.P. acknowledges the Department of Science and Technology, Government of India, for the SERC young scientist project award. This paper is NIO contribution number ........

Funding: SERC, DST, Government of India

\section{Compliance with Ethical Standards}

Conflict of Interest: The authors declare they have no conflict of interest.

\section{Author contributions}

Sathish K: performed all the experiments and statistical analysis, data interpretation; JS Patil: Original concept, experiment planning, data interpretation, manuscript elaboration and also supervised all works.

\section{Ethics approval and consent to participate}

Not applicable as this study is not related to human and animals

Consent for publication: Not applicable

Availability of data and material: Please contact author for data requests

\section{References}

1. Hallegraeff GM, Bolch C (1992) Transport of diatom and dinoflagellate resting spores in ships' ballast water: implications for plankton biogeography and aquaculture. J Plank Res 14(8): 1067 1084.

2. Godhe A, Härnström K (2010) Linking the planktonic and benthic habitat: genetic structure of the marine diatom Skeletonema marinoi. Mol Ecol 19: 4478 - 4490.

3. Tahvanainen P, Alpermann TJ, Figueroa RI, John U, Hakanen P, et al (2012) Patterns of Post-Glacial Genetic Differentiation in Marginal Populations of a marine microalga. PLoS ONE (1): e53602. doi:10.1371/journal.pone.0053602

4. Ellegaard M, Godhe A, Ribeiro S (2018) Time capsules in natural sediment archives-Tracking phytoplankton population genetic diversity and adaptation over multidecadal timescales in the face of environmental change. Evol Appl 11: 11 - 16.

5. McQuoid M, Hobson LA, (1995) Importance of resting stages in diatom seasonal succession. European J Phycol 31: 44 - 50. 
6. Sundqvist L, Godhe A, Jonsson RP, Sefbom J, (2018) The anchoring effect-long-term dormancy and genetic population structure. The ISME J 12: 2929 - 2941.

7. Ellegaard M, Ribeiro S (2018) The long-term persistence of phytoplankton resting stages in aquatic 'seed banks'. Biol Rev 93:166-183, https://doi.org/10.1111/brv.12338

8. Trottet A, Wilson B, Xin GSW, George C, Casten L, Schmoker C, Rawi NSBM, Siew MC, Larsen O, Eikaas SH, Tun K, Drillet G (2018) Resting Stage of Plankton Diversity from Singapore Coastal Water: Implications for Harmful Algae Blooms and Coastal Management. Environ Manag 61: 275 - 290.

9. Anil AC, Mitbavkar S, DeSilva MS, Hegde S, DeCosta PM, Meher SS, Banerjee D (2007) Effect of aging on survival of benthic diatom propagules. J Exp Mar Biol Ecol 343(1): 37 - 43.

10. Härnström K, Ellegaard M, Andersen TJ, Godhe A (2011) Hundred years of genetic structure in a sediment revived diatom population. Proc Nat Acad Sci 108: 4252 - 4257.

11. Ribeiro S, Berje T, Lundholm N, Andersen TJ, Abrantes F, Ellegaard M (2011) Phytoplankton growth after a century of dormancy illuminates past resilience to catastrophic darkness. Nat Com 2: 311.

12. McQuoid M (2002) Pelagic and benthic environmental controls on the spatial distribution of a viable diatom prapagule bank of the Swedish west. J Phycol 38: $881-893$.

13. Mcquoid M, Godhe A, Nordberg K (2002) Viability of phytoplankton resting stages in the sediments of a coastal Swedish fjord. Eur J Phycol 37: 190 - 201.

14. McQuoid M, Godhe A (2004) Recruitment of coastal planktonic diatoms from benthic versus pelagic cells: variation in bloom development and species composition. Limnol Oceanogr 49(4): $1123-$ 1133.

15. Lewis J, Harris ASD, Jones KJ, Edmonds RL (1999) Long-term survival of marine planktonic diatoms and dinoflagellates in stored sediment samples. J Plank Res 21: $343-354$.

16. Riaux-Gobin C (1996) Dity/um brightwellii (Bacillariophyceae): resting spores at the surface of a shallow sediment (Gulf of Lions, Mediterranean) and revival tests. Phycologia 35: 368 - 371.

17. Imai I, Itakura S, Itoh K (1990) Distribution of diatom resting cells in sediments of Harima-Nada and Northern Hiroshima Bay, the Seto Inland Sea, Japan. Bull Coast Oceanogr 28: 75 - 84.

18. Patil JS, Anil AC (2008) Temporal variation of diatom benthic propagules in a monsoon-influenced tropical estuary. Cont Shelf Res 28: 2404 - 2414.

19. Casabianca S, Capellacci S, Ricci F, Andreoni F, Russo T, Scardi M, Penna A (2020) Structure and environmental drivers of phytoplanktonic resting stage assemblages in the central Mediterranean Sea. Mar Ecol Prog Ser 639: 73 - 89.

20. Fukai Y, Matsuno K, Fujiwara A, Yamaguchi A (2019) The community composition of diatom resting stages in sediments of the northern Bering Sea in 2017 and 2018: the relationship to the interannual changes in the extent of the sea ice. Polar Biol 42: 1915 - 1922.

21. Tsukazaki C, Ishii K, Matsuno K, Yamaguchi A, Imai I (2018) Distribution of viable resting stage cells of diatoms in sediments and water columns of the Chukchi Sea, Arctic Ocean. Phycologia 57: $440-$ 452 . 
22. Sicko-Goad L, Stoermer EF, Fahnenstiel G (1986) Rejuvenation of Melosira granulata (Bacillariophyceae) resting cells from the anoxic sediments of Douglas Lake, Michigan. I. Light microscopy and ${ }^{14} \mathrm{C}$ uptake. J Phycol 22: $22-28$.

23. Eilertsen HC, Sandberg S, Tøllefsen H (1995) Photoperiodic control of diatom spore growth: a theory to explain the onset of phytoplankton blooms. Mar Ecol Prog Ser 116: $303-307$.

24. McQuoid M (2005) Influence of salinity on seasonal germination of resting stages and composition of microplankton on the Swedish west coast. Mar Ecol Prog Ser 289: $151-163$.

25. McQuoid M, Hobson LA (1996) Diatom resting stages. J Phycol 32: 889 - 902.

26. Ishikawa A, Furuya K (2004) The role of diatom resting stages in the onset of the spring bloom in the East China Sea. Mar Biol 145: 633 - 639.

27. Itakura S, Imai I, Itoh K (1997) "Seed bank" of coastal planktonic diatoms in bottom sediments of iroshima Bay, Seto Inland Sea, Japan. Mar Biol 128: 497 - 508.

28. Kremp A (2001) Effects of cyst resuspension on germination and seeding of two bloom-forming dinoflagellates in the Baltic Sea. Mar Ecol Prog Ser 216: 57 - 66.

29. Härnström K, Godhe A, Saravanan V, Karunasagar I, Karunasagar I, Sofi Rehnstam-Holm A (2007) Tropical phytoplankton community development in mesocosms inoculated with different life stages. Mar Ecol Prog Ser 346: 75 - 88.

30. Patil JS, Anil AC (2011) Variations in phytoplankton community in a monsoon-influenced tropical estuary. Environ Monit Assess 182: 191 - 200.

31. Patil, J.S. \& A. C. Anil, 2015. Effect of monsoonal perturbations on the occurrence of phytoplankton blooms in a tropical bay. Mar Ecol Prog Ser 530: 77 - 92.

32. Piredda R, Sarno D, Lange BC, Tomasino PM, Zingone A, Montresor M (2017) Diatom Resting Stages in Surface Sediments: A Pilot Study Comparing Next Generation Sequencing and Serial Dilution Cultures. Crypt Algol 38(1): $31-46$.

33. Guillard RRL, Ryther JH (1962) Studies of marine planktonic diatoms. I. Cyclotella nana Hustedt and Detonula confervacea Cleve. Can J Microbiol 8: 229 - 239.

34. Patil JS, Anil AC (2019) Assessment of phytoplankton photo-physiological status from a tropical monsoonal estuary. Ecol Indicat 103: $289-300$.

35. Parsons TR, Maita Y, Lalli CM (1984) A manual of chemical and biological methods for sea water analysis. Oxford: Pergmon Press.

36. Patil JS, Anil AC (2019) Simulation experiments to elucidate variable fluorescence as a potential proxy for bulk microalgal viability from natural water, sediments and biofilms: Implication in ships ballast water management. J Environ Manag 222: 242 - 249.

37. Tomas C (1997) Identifying marine phytoplankton. Academic Press, San Diego, CA

38. Burge DRL, Edlund BM, Frisch D (2018) Paleolimnology and resurrection ecology: The future of reconstructing the past. Evol Appl 11: $42-59$. 
39. Sundar D, Unnikrishnan AS, Michael GS, Kankonkar A, Nidheesh AG, Subeesh MP (2015) Observed variations in stratification and currents in the Zuari estuary, west coast of India. Environ Earth Sci 74: 6951 - 6965.

40. Pelusi A, Santelia EM, Benvenuto G, Godhe A, Montresor M (2020b) The diatom Chaetoceros socialis: spore formation and preservation. Eur J Phycol 55(1): 1 - 10.

41. Pelusi A, Margiotta F, Passarelli A, Ferrante IM, d'Alcalà RM, Montresor M (2020a) Density-dependent mechanisms regulate spore formation in the diatom Chaetoceros socialis. Limnol Oceanogr Lett doi: 10.1002/lol2.10159

42. Kuwata A, Takahashi M (1999) Survival of resting spores and resting cells of the marine planktonic diatom Chaetoceros pseudocurvicetus under fluctuating nitrate conditions. Mar Biol 134: 471 - 478.

43. Shikata T, Nukata A, Yoshikawa S, Matsubara T, et al (2009) Effects of light quality on initiation and development of meroplanktonic diatom blooms in a eutrophic shallow sea. Mar Biol 156: 875 - 889 .

44. Shikata T, Iseki M, Matsunaga S, Higashi Y, Kamei Y, Watanabe M (2011) Blue and red light-induced germination of resting spores in the red-tide diatom Leptocylindrus danicus. Photochemist Photobiol 87: 590 - 597.

45. Hollibaugh JT, Seibert DLR, Thomas WH (1981) Observation on the survival and germination of resting spores of three Chaetoceros (Bacillariophycea) species. J Phycol 17: 1 - 9.

46. Shikata T, Nagasoe S, Matsubara T, Yoshikawa S, et al (2008) Factors influencing the initiation of blooms of the raphidophyte Heterosigma akashiwo and the diatom Skeletonema costatum in a port in Japan. Limnol Oceanogr 53: 2503 - 2518.

47. Montresor M, Prisco CD, Sarno D, Margiotta F, Zingone A (2013) Diversity and germination patterns of diatom resting stages at a coastal Mediterranean site. Mar Ecol Prog Ser 484: 79 - 95.

48. Jewson DH, Granin NG, Zhdanov AA, Gorbunova LA, Bondarenko NA, Gnatovsky RY (2008) Resting stages and ecology of the planktonic diatom Aulacoseira skvortzowii in Lake Baikal. Limnol Oceanogr 53: 1125 - 1136.

49. French FW, Hargraves PE (1985) Spore formation in the life cycles of the diatoms Chaetoceros diadema and Leptocylindrus danicus. J. Phycol 21: 477 - 483.

50. Anderson OR (1975) The ultrastructure and cytochemistry of resting cell formation in Amphora coffeaeformis (Bacillariophyceae). J Phycol 1: 272 - 281.

\section{Figures}



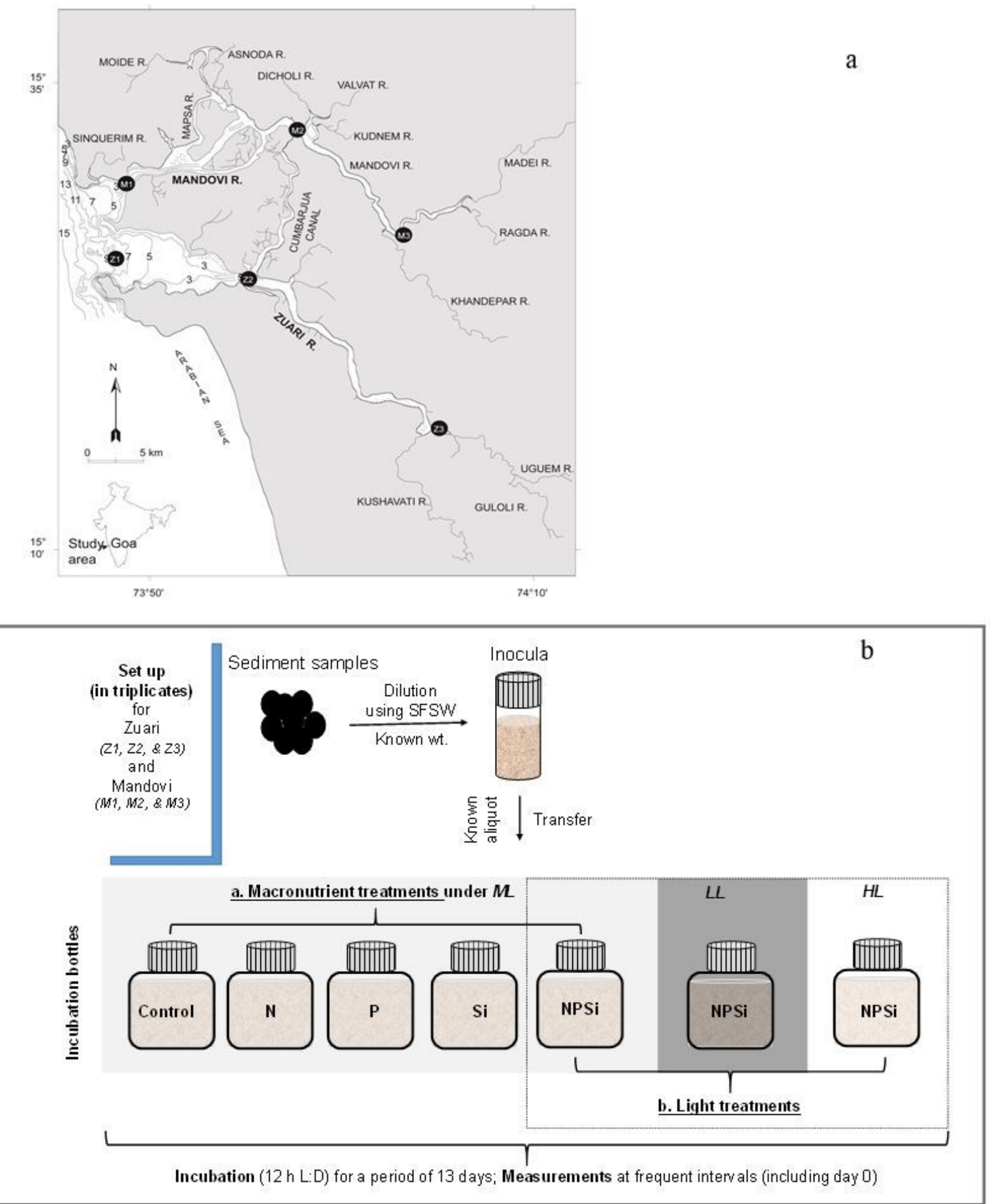

\section{Figure 1}

(a) Location of sediment collection for germination experiments along Mandovi (M1 - FDownstream; M2 - Midstream; M3 - Upstream) and Zuari rivers (Z1 - Downstream; Z2 - Midstream; Z3 - Upstream). (b) Schematic presentation of experimental design to elucidate responses of phytoplankton benthic propagule (PBP) representing downstream (Z1 and M1), midstream (Z2 and M2), and upstream (Z3 and $\mathrm{M} 3$ ) locations of the Zuari $(\mathrm{Z})$ and Mandovi $(\mathrm{M})$ rivers to macro-nutrient enrichment (nitrate $-\mathrm{N}$, 
phosphate - P, silicate - Si, and NPSi) and different light intensities (high light - HL, medium light - ML and low light - LL). SFSW - sterile filtered seawater
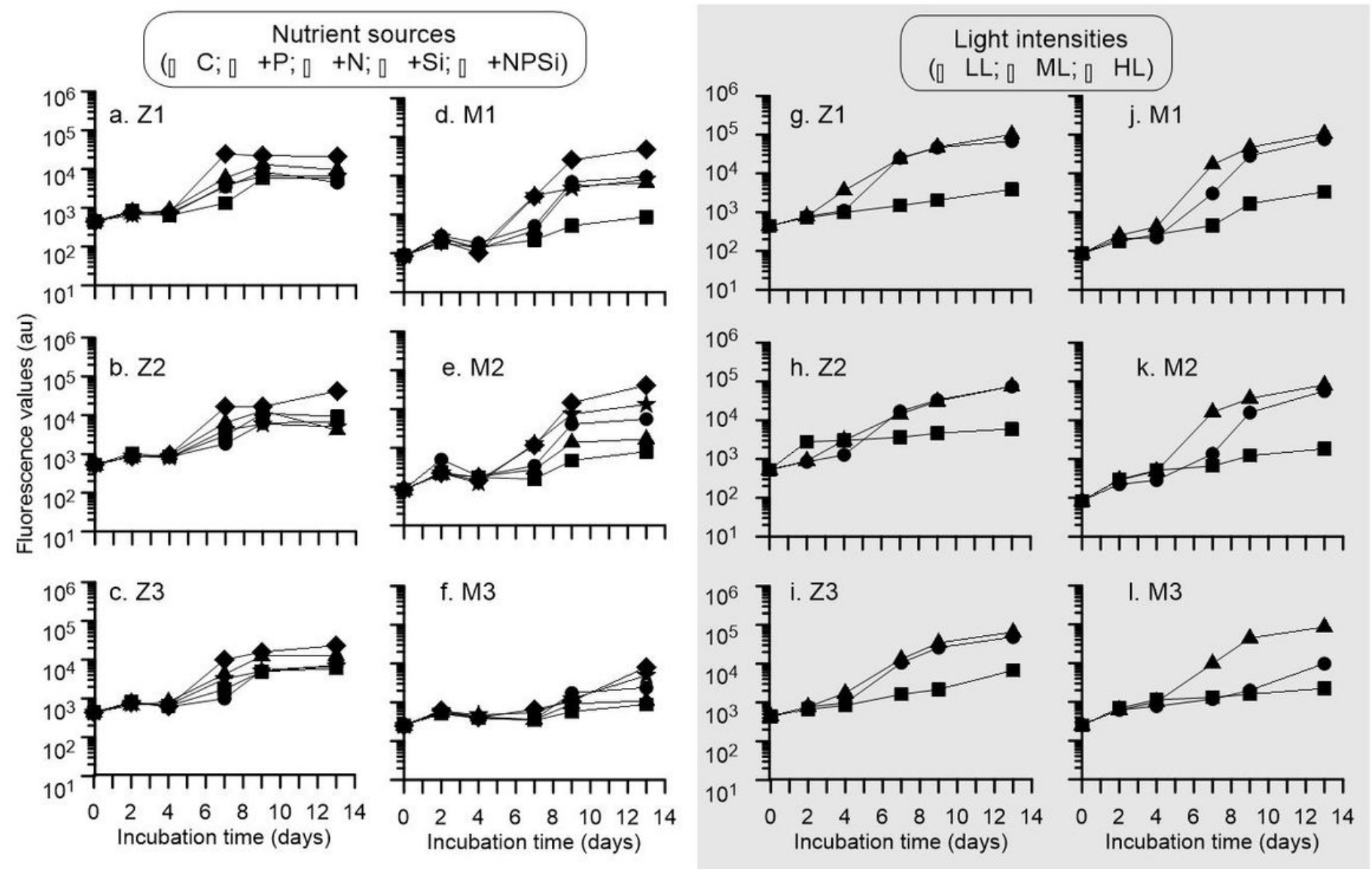

Figure 2

Effect of nutrient sources (N, P, Si, and NPSi) and different light intensities (high light - HL, medium light - ML, and low light - LL) on chlorophyll a fluorescence of phytoplankton benthic propagules collected from downstream to upstream locations along Mandovi and Zuari rivers concerning incubation days. Error bars are not shown as they will be difficult to read due to overlapping. 

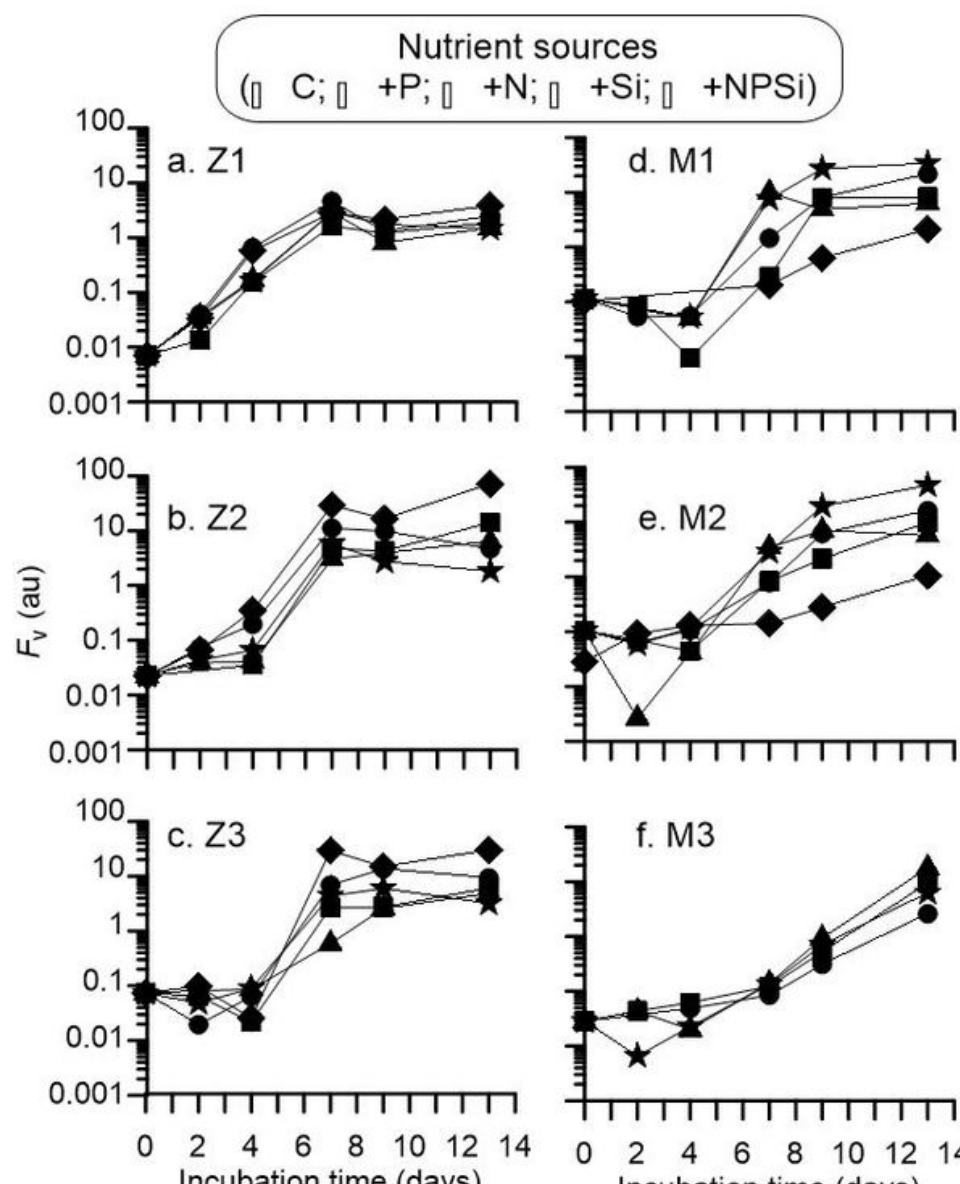

Incubation time (days)
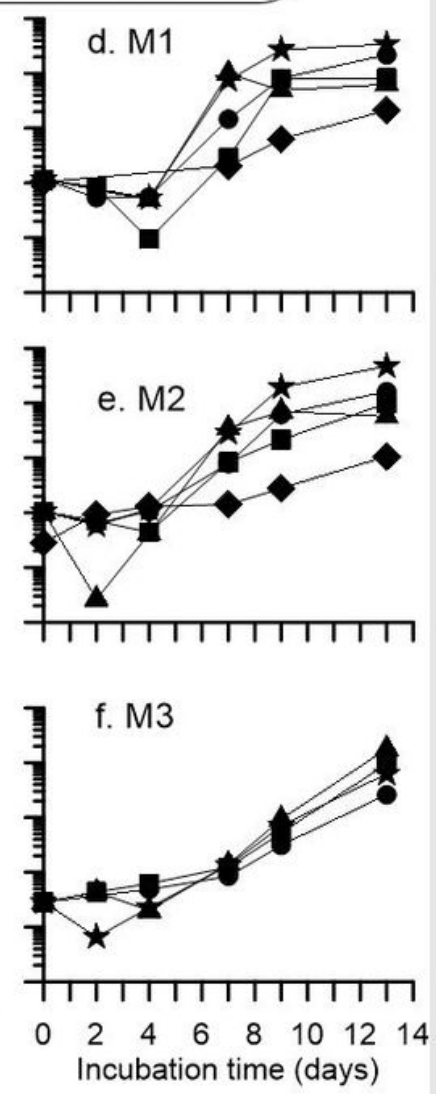
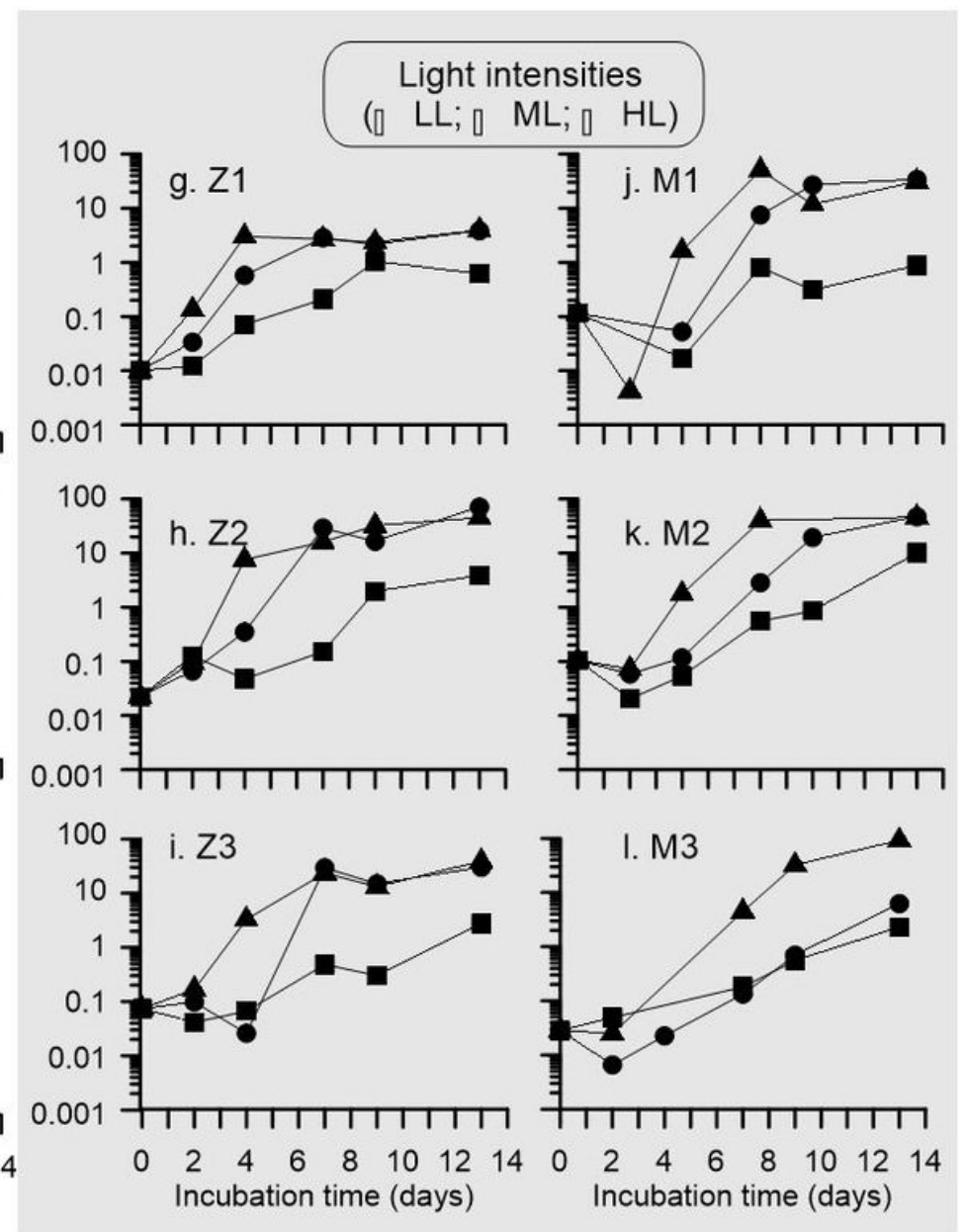

\section{Figure 3}

Effect of nutrient sources (N, P, Si, and NPSi) and different light intensities (high light - HL, medium light - ML, and low light - LL) on variable fluorescence (Fv) of phytoplankton benthic propagules collected from downstream to upstream locations along Mandovi and Zuari rivers concerning incubation days. Error bars are not shown as they will be difficult to read due to overlapping. 


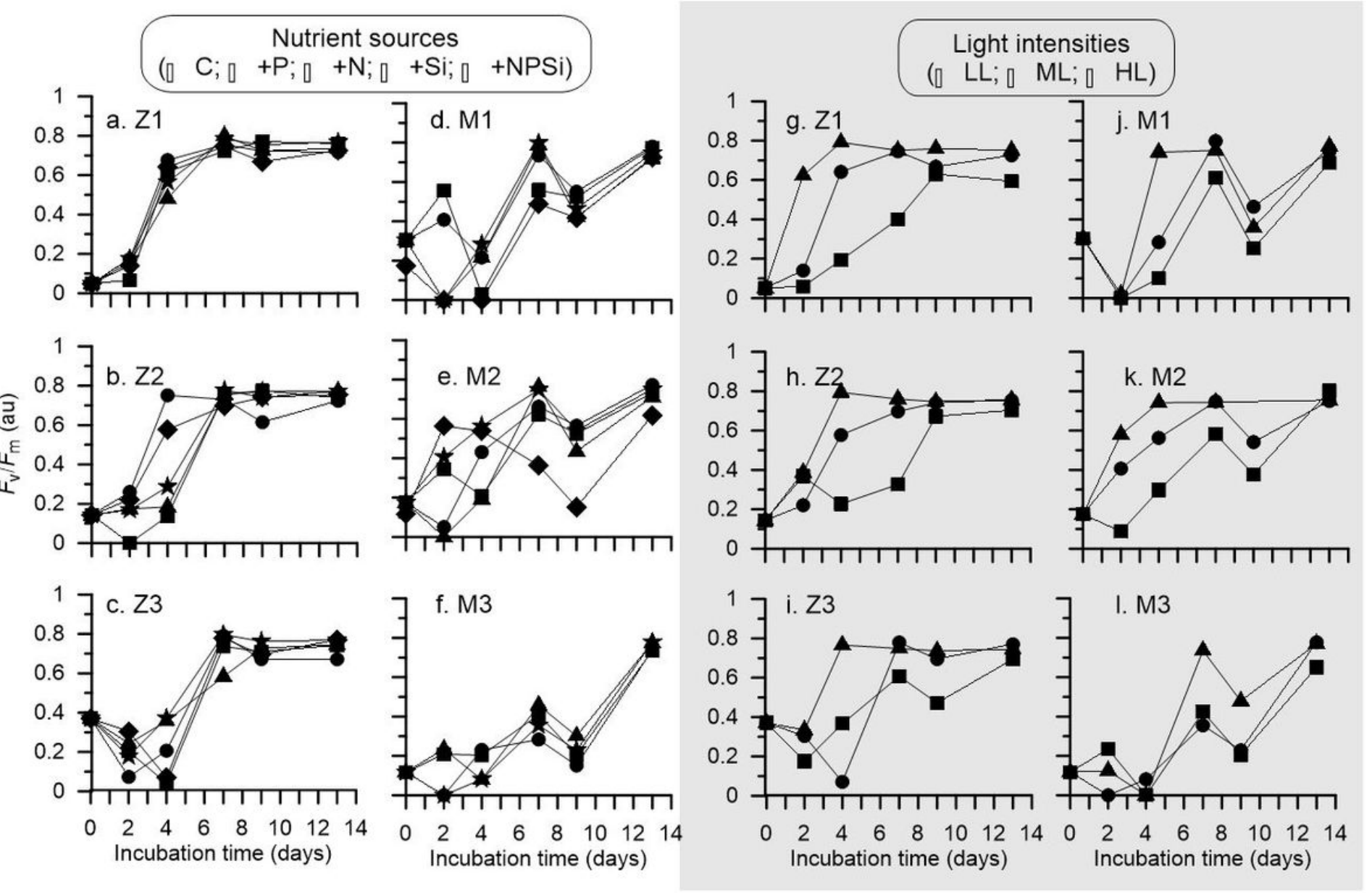

Figure 4

Effect of nutrient sources (N, P, Si, and NPSi) and different light intensities (high light - HL, medium light - ML and low light - LL) on photosynthetic efficiency (Fv/Fm) of phytoplankton benthic propagules collected from downstream to upstream locations along Mandovi and Zuari rivers concerning incubation days. Error bars are not shown as they will be difficult to read due to overlapping. 

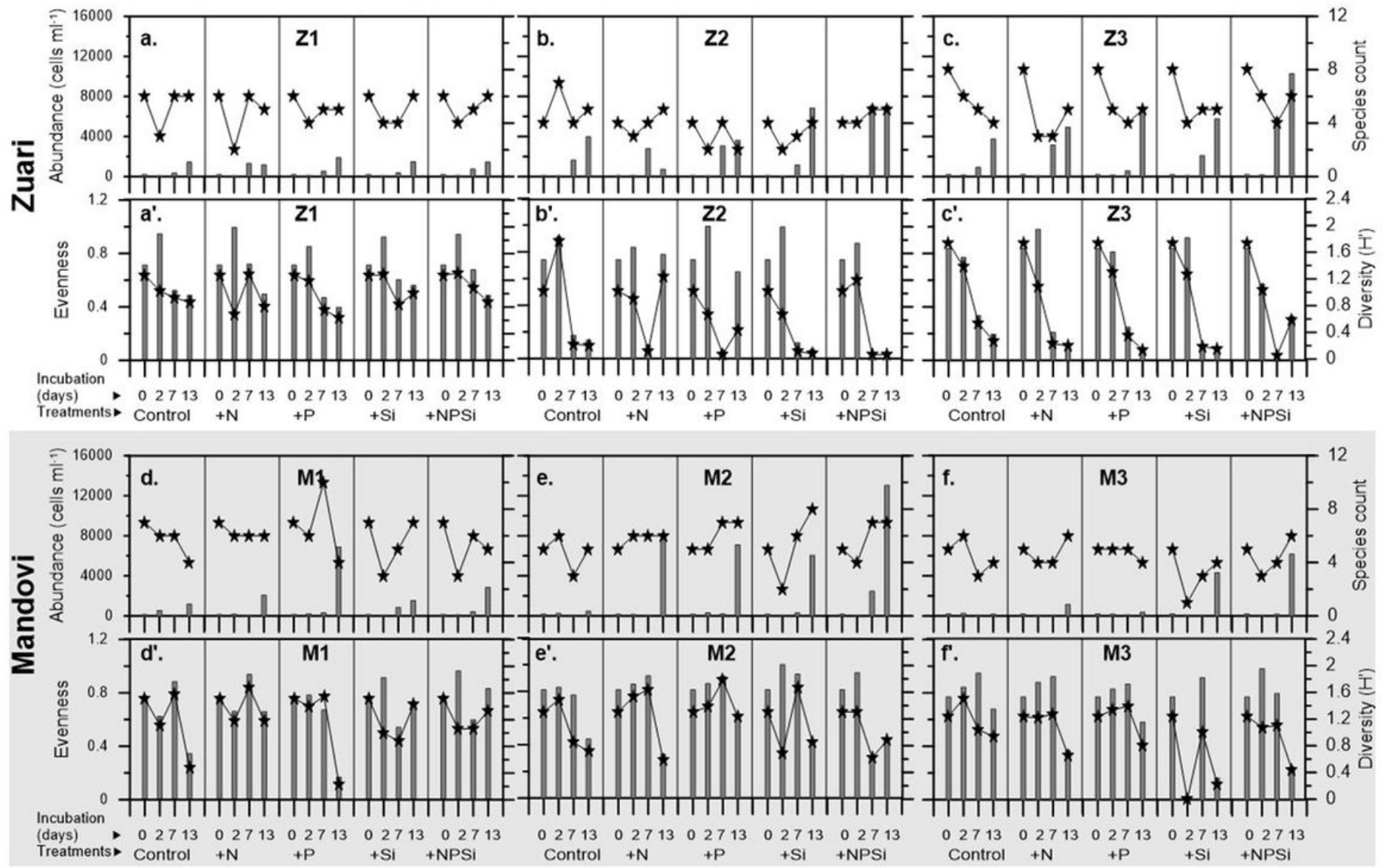

Figure 5

Effect of nutrient sources (N, P, Si, and NPSi) on the abundance (bar), species count (line) diversity (line), and evenness (bar) of phytoplankton benthic propagules collected from downstream to upstream locations along Mandovi and Zuari rivers concerning incubation days.

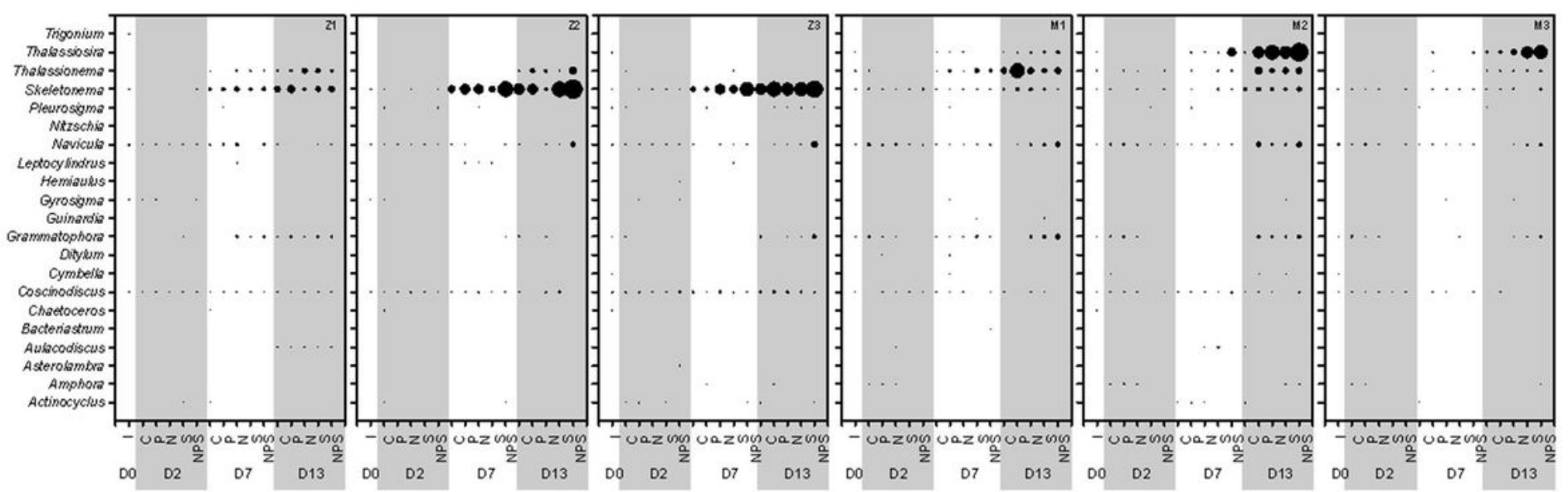

Figure 6

Variations in the species composition of germinated phytoplankton benthic propagules under different nutrient sources (N, P, Si, and NPSi) for different locations (downstream to upstream locations) along 
Mandovi and Zuari rivers concerning incubation days.

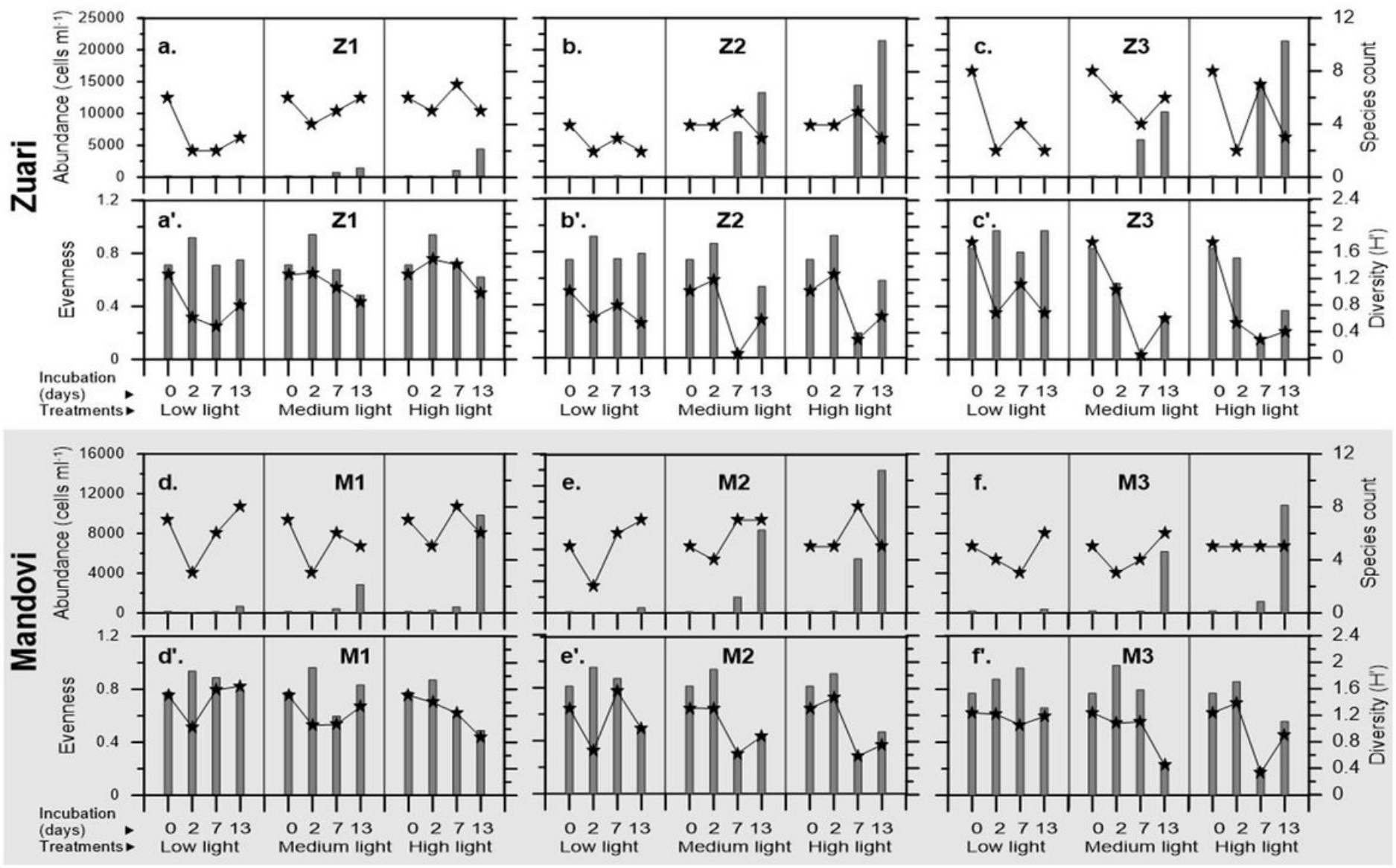

\section{Figure 7}

Effect of different light intensities (high light - HL, medium light - ML, and low light - LL) on the abundance (bar), species count (line), diversity (line), and evenness (bar) of phytoplankton benthic propagules from downstream to upstream locations along Mandovi and Zuari rivers concerning incubation days.
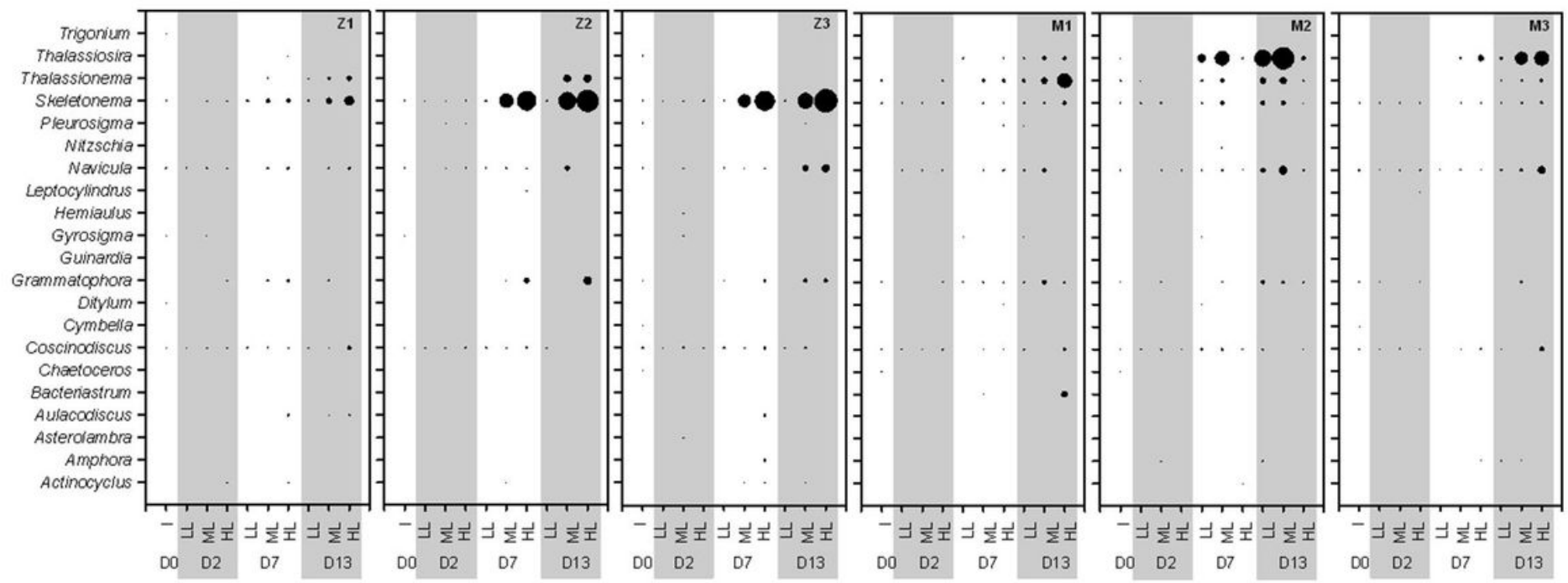
Figure 8

Variations in the species composition of germinated phytoplankton benthic propagules under different light intensities (high light - HL, medium light $-M L$, and low light - LL) for different locations (downstream to upstream locations) along Mandovi and Zuari rivers concerning incubation days.

\section{Supplementary Files}

This is a list of supplementary files associated with this preprint. Click to download.

- SupplementatyfiguresMECO.doc 